\title{
Intergenerational differences in personal relationship to nature
}

\author{
Markéta Vacínová, Tomáš Matějček
}

Envigogika 2013/VIII/2- Recenzované články/ Reviewed Papers

Publikováno/Published 06 09. 2013

\section{DOI: http://dx.doi.org/10.14712/18023061.384}

\begin{abstract}
This paper summarizes the results of research undertaken on pupils in the 8th and 9th grade of elementary school (or the corresponding grades of grammar schools) and their parents on selected aspects of their personal relationship to nature. The research was conducted through a questionnaire survey which was completed by 222 respondents, of whom half were pupils, the other half their parents. Our research showed that there are certain differences in personal relationships to nature between the students and their parents. The two surveyed groups differed most in their feeling the need to be in the countryside: students practiced mainly "modern" activities in the countryside, while their parents practiced more "classic" or "traditional" pursuits.
\end{abstract}

\section{Key words}

Environmental literacy, pedagogical research, personal relationship towards nature, environmental education. 


\section{Introduction}

One's personal relationship to nature is a very important aspect of the human personality because it significantly affects lifestyle choices, human behaviour and the environment itself. The relationship to nature is individual varying between members of different social groups depending on age, gender, social status etc. In our study we focused on the differences in this relationship between elementary school pupils and their parents. We were interested in potential differences between the groups. Both groups come from a similar social background, their social status differes, as does their capacity to affect the environment. For the purposes of this paper, we consider 'nature' as everything that has not been created by human activity, including the extensively used environment that we term 'countryside' in this study.

The issue of the personal relationship to nature has been very closely examined by Krajhanzl (2009, 2010). He uses a multidimensional approach in which personal attitudes towards nature can be described in at least 5 ways: the need for contact with nature, the ability to be in contact with nature, environmental sensitivity, environmental awareness and attitude towards nature. Each person then experiences a feeling of being in harmony with nature to a greater or lesser extent depending on where they stand on each of these aspects. The author points out that these dimensions cannot be separated and all of them have to be taken into consideration when examining personal relationships to nature.

Another way of describing one's personal relationship to nature can be found in the concept of environmental inclusion (see Schultz 2002 cit. in Krajhanzl 2010). This psychological model also rates several aspects of the person-nature relationship; a connection with nature (how much the person considers himself as part of the nature), positive feelings toward nature and the commitment to preserve nature.

A concept commonly used in relation to the personal relationship to nature is environmental literacy which is considered by many authors as a multidimensional model of the relationship between humans and nature. For example according to McBeth and Volk (2010) the environmentally literate person should be observant, has environmental knowledge, takes a position towards the environment, knows how, in theory, to act correctly towards the environment and then actually does so. Also, according to Marcinkowski, Rehrig and Simmons (1998) in Negev et al. (2008), environmental literacy represents the connection between ecological and environmental knowledge, attitudes in environmental issues, cognitive skills in analysis of environmental issues, an active approach in preserving the environment and consideration of the degree of environmental sensitivity. Similarly, Máchal (2000) understands environmental literacy as basic knowledge and skills needed to understand patterns of interaction between humans and the biosphere, to understand practical solutions of environmental problems and to promote principles of sustainable development into everyday family life and society. In the school environment, we can also consider environmental literacy as a result of ecological education demonstrating itself in civil life and working activities (Kvasničková 2007).

Research on environmental literacy of primary and secondary school students focussing not only on knowledge, but also on skills, attitudes and activeness of approach, was conducted by Kulich and Dobiášová (2003), Činčera and Štěpánek (2007), Erdogan and Ok (2011), Kasková (2008), Negev et al. (2008), Tuncer et al. (2005), Vacínová (2011), and Zecha (2010) etc.

Research by Kulich and Dobiášová (2003) was one of the first studies of environmental literacy of Czech primary and secondary school students. The results 
showed respondents' low level of environmentally friendly attitudes and knowledge. Also, considerable ignorance of local natural landscapes and the very low level of students' positive attitude to the place where they live were detected.

Činčera and Štěpánek (2007) found that there was a mismatch between declared attitudes and actual consumer behaviour in the majority of respondents. Their results also showed that only a small minority of respondents invest time and money in proenvironmental behaviour (e. g. considering the impact on the environment when buying goods or contributing financially to the protection of nature).

Kasková (2008) presented very similar conclusions. almost significantly, the results of her research highlighted the differences between respondents depending on their place of residence, respectively their place of birth.

Research by Vacínová (2011) showed that students of eco-schools in the Czech Republic don't show a higher degree of pro-environmental behaviour or knowledge compared to students of non-specialist schools. In accordance with the results of Kulich and Dobiášová (2003) this research showed a low level of environmentally friendly behaviour among Czech students.

Tuncer et al. (2005) showed that the level of environmental literacy of young people in Turkey is influenced by school type (there are differences between private and public schools) and gender (girls have a more positive environmental attitude than boys).

Zecha (2010) compared the results of environmental knowledge, attitudes and conduct of German and Spanish students. The results show that there are cultural influences in the scales of knowledge, attitudes and actions.

An overview of published studies shows a general agreement that a personal relationship to nature and environmental literacy differs between individuals and between different groups of individuals.

\section{Methods of research}

The research was undertaken in January 2013 among 135 students from $8^{\text {th }}$ and $9^{\text {th }}$ grade of Londýnská Elementary school (Prague 2) and students of the same age from Nad Štolou Gymnasium (Prague 7) and their parents. Pupils completed the questionnaire under the supervision of the teachers during class time. Their parents completed it at home and were asked to bring it back within a week. It was not determined which one of the parents should complete the questionnaire (it depended on individual willingness and on the individual situation in each family).

For the evaluation, we excluded the questionnaires of students whose parents did not provide questionnaire responses - this relates to 24 of the students' questionnaires so ultimately 111 students' questionnaires and the same number of their parents' questionnaires were included in the research (totalling 222 respondents).

The research concentrated on the practical side of the respondents' lives - their habits, experiences, sensitivity and an active approach to the events around themselves.

W sought answers to the following answers:

1) How can the personal relationship of pupils towards nature be described?

2) How do students' relationships to nature differ from their parents'? 
The questionnaire consisted of 11 parts formed by sub-questions. Closed questions (with dichotomous answers - yes/no or multiple-choice), open questions with space for open answers and also Likert scale-type questions were used. The time needed to complete the questionnaire was approximately 15-20 minutes, which was acceptable for the pupils and the parent respondents (and also for teachers as it did not take up too much class time. The questionnaire was assembled to cover all 5 dimensions of the personal relationship towards nature as defined by Krajhanzl (2010). The full text of the questionnaire is included in this article (see Appendix 1).

Quantitative and qualitative methods were used to evaluate the obtained results. In open questions $(6,8,10)$, unifying categories were defined according to the content of the responses.

\section{Results}

\section{Questions focused on the need for contact with nature}

The purpose of questions 1, 2, 4 and 8 (see Appendix 1) was to explore the extent of respondents' need to have contact with nature. Questions 1 and 2 focused on the occurrence of natural elements and living organisms in the households of the respondents. Question 1 offered a four-point scale of responses focused on quantity of occurrences in the household. Both groups agreed that plants and natural elements do appear in their household at a rate they would consider common. Two thirds of respondents have pets (question 2), mostly because they bring pleasure and joy. The most common reason for why respondents do not have a pet is allergy in family or lack of time to take care of the pet. Most pets are usually cats and dogs. The assumption was that responses from pupils and parents would be identical. That assumption was correct, which gives respondents' answers some credibility.

The goal of question 4 was to find out how many respondents feel the need to visit the countryside. Both groups of respondents mostly answered (53\%) that they go for a walk to nature from time to time, not regularly, but only when they are not busy. The second most common response was that they made "regular visits to nature", chosen by $25 \%$ of parents. On the other hand $22 \%$ of the pupils go to the countryside just because of their parents (the second most common response of the pupils). The results seem to indicate that the older generation has a greater need to visit the countryside than the pupils (Figure 1). However, we must take into account that this result may not be significant because it is based on the answer to only one question on this topic, which might be influenced by other factors. 


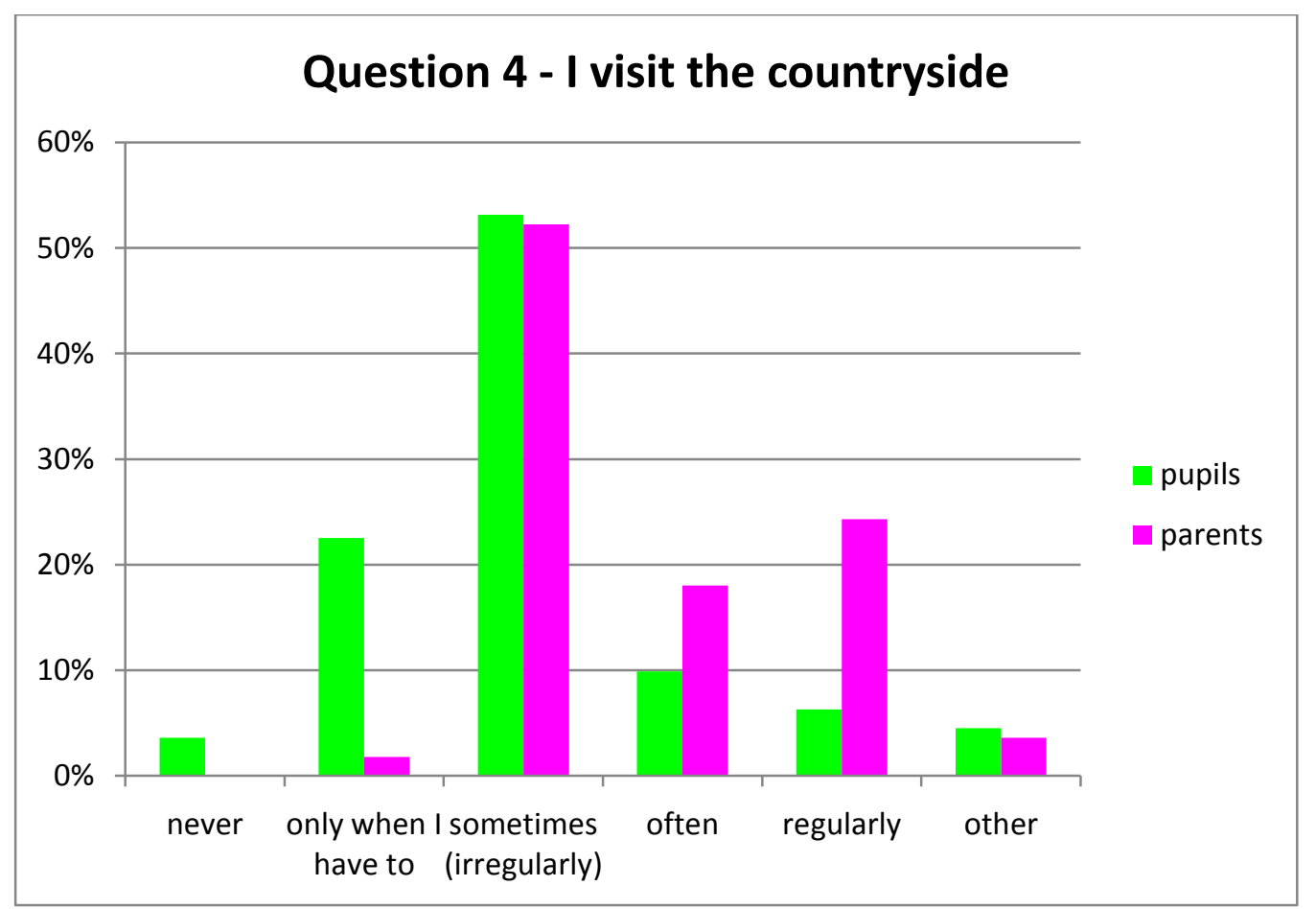

Figure 1. Evaluation of Question 4 - "I visit the countryside"

Question 8 attempted to find out which activities the respondents tried or regularly practice when visiting the countryside. The most common activities among both pupils and parents were 3 activities, which were selected by an almost equal number of respondents. These activities were cycling, making campfires and walking (Figure 2). Both groups agreed that the least practiced activity is the organised group with a focus on nature (chosen by just less than $7 \%$ of respondents). A big difference between parents and pupils was in the practice of "modern" activities (mostly canoeing and climbing), which is markedly more common for pupils (Figure 2). 


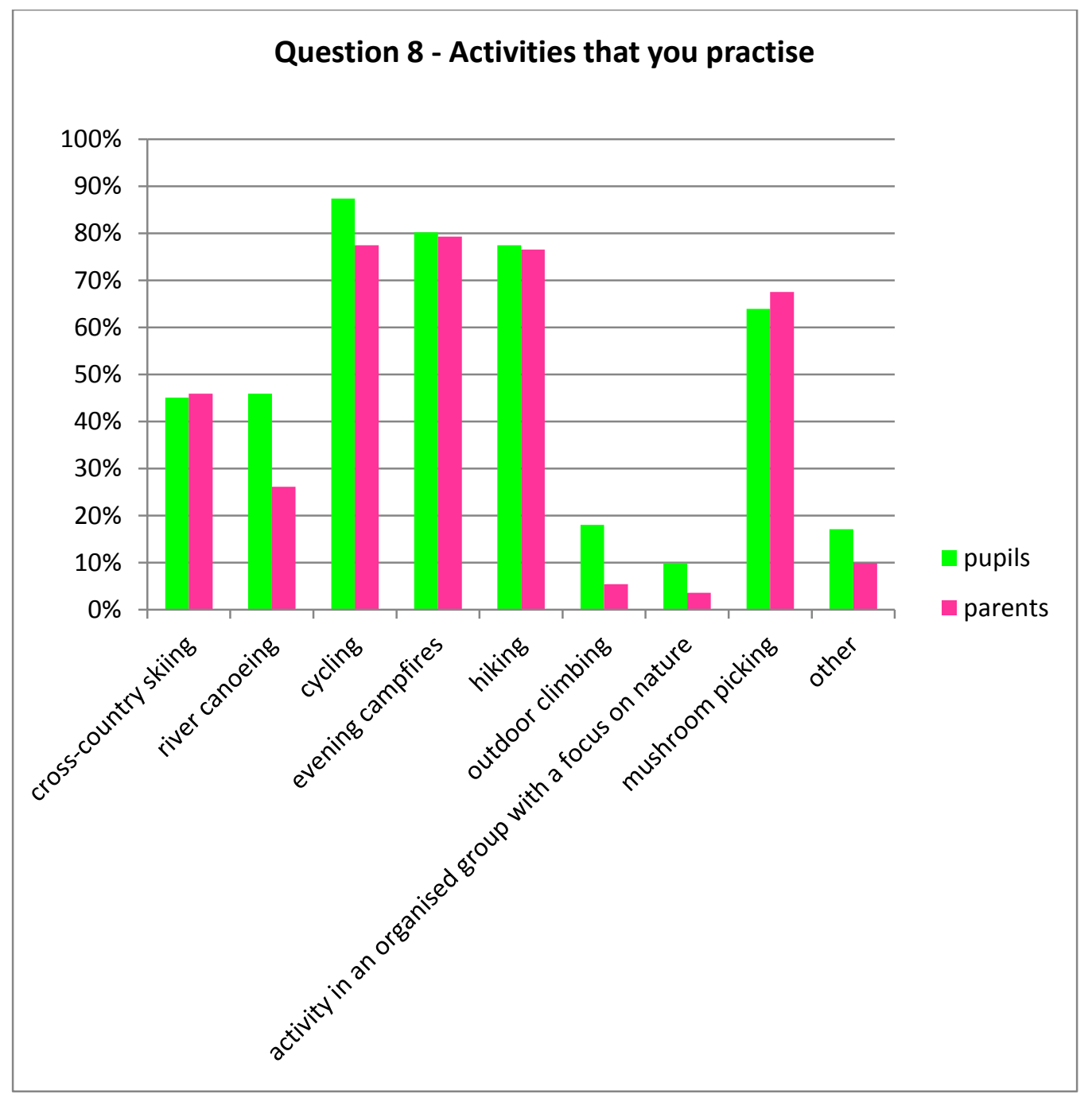

Figure 2. Evaluation of Question 8 - Activities that you practice

\section{Questions focused on the ability to have respectful contact with nature}

Some claims focused on the ability to have respectful contact with nature were found in question 3, which was composed of a set of 6 statements in which the respondents selected the degree to which they agreed with the statements. The results of question 3 are presented in Table 1.

Claim 3/III was focused on orientation in nature. It is apparent from the results that parents feel more sure about their ability to orient themselves in nature than their children (while $48,6 \%$ of parents fully agree they do not have a problem with orientation in nature and $29,7 \%$ of parents rather agree, the shares of the pupils are almost completely the opposite).

In the claim 3/VI ("If I'm in a forest during a thunderstorm, I hide under a tree to protect myself from rain."), the answer was almost identical; the vast majority of respondents didn't agree with this (potentially dangerous) claim. 
Table 1 - Evaluation of results from question 3 (claims 3/I, 3/II, 3/V and 3/VI are commented in the text; for full text of claims see questionnaire in Appendix 1, question 3)

\begin{tabular}{|l|l|l|l|l|l|l|l|l|}
\hline \multicolumn{2}{|l|}{ upils } & \multicolumn{3}{|l|}{ parents } \\
\cline { 2 - 9 } & $\begin{array}{l}\text { strongly } \\
\text { agree }\end{array}$ & $\begin{array}{l}\text { somewh } \\
\text { at agree }\end{array}$ & $\begin{array}{l}\text { somewhat } \\
\text { disagree }\end{array}$ & $\begin{array}{l}\text { strongly } \\
\text { disagree }\end{array}$ & $\begin{array}{l}\text { strongly } \\
\text { agree }\end{array}$ & $\begin{array}{l}\text { somewha } \\
\text { t agree }\end{array}$ & $\begin{array}{l}\text { somewhat } \\
\text { disagree }\end{array}$ & $\begin{array}{l}\text { strongly } \\
\text { disagree }\end{array}$ \\
\hline I. & $41,4 \%$ & $42,3 \%$ & $11,7 \%$ & $4,5 \%$ & $73,0 \%$ & $16,2 \%$ & $16,2 \%$ & $1,8 \%$ \\
\hline II. & $23,4 \%$ & $44,1 \%$ & $25,2 \%$ & $6,3 \%$ & $45,0 \%$ & $43,2 \%$ & $9,9 \%$ & $1,8 \%$ \\
\hline III. & $29,7 \%$ & $45,9 \%$ & $18,9 \%$ & $5,4 \%$ & $48,6 \%$ & $29,7 \%$ & $18,9 \%$ & $2,7 \%$ \\
\hline IV. & $21,6 \%$ & $44,1 \%$ & $28,8 \%$ & $5,4 \%$ & $71,2 \%$ & $24,3 \%$ & $3,6 \%$ & $1,8 \%$ \\
\hline V. & $5,4 \%$ & $29,7 \%$ & $40,5 \%$ & $23,4 \%$ & $11,7 \%$ & $16,2 \%$ & $27,0 \%$ & $45,0 \%$ \\
\hline VI. & $3,6 \%$ & $7,2 \%$ & $18,9 \%$ & $69,4 \%$ & $2,7 \%$ & $9,9 \%$ & $13,5 \%$ & $73,9 \%$ \\
\hline
\end{tabular}

Question 10 was focused on the validation of exact skills and experiences which are related to the relationship to nature. We could divide these experiences into "hiking and camping" ( $a, b, c, e, g)$ and "taking care of pets and gardening" (d, f). With this division we can see some differences between the pupils and their parents (with some exception in claim e, Figure 3). The pupils chose mostly "taking care of pets and gardening" experiences, while their parents chose "hiking and camping" more often (Figure 3). Results can be compared because this exact question was already used in a previous investigation (Vacínová 2011) - see Figure 3. 


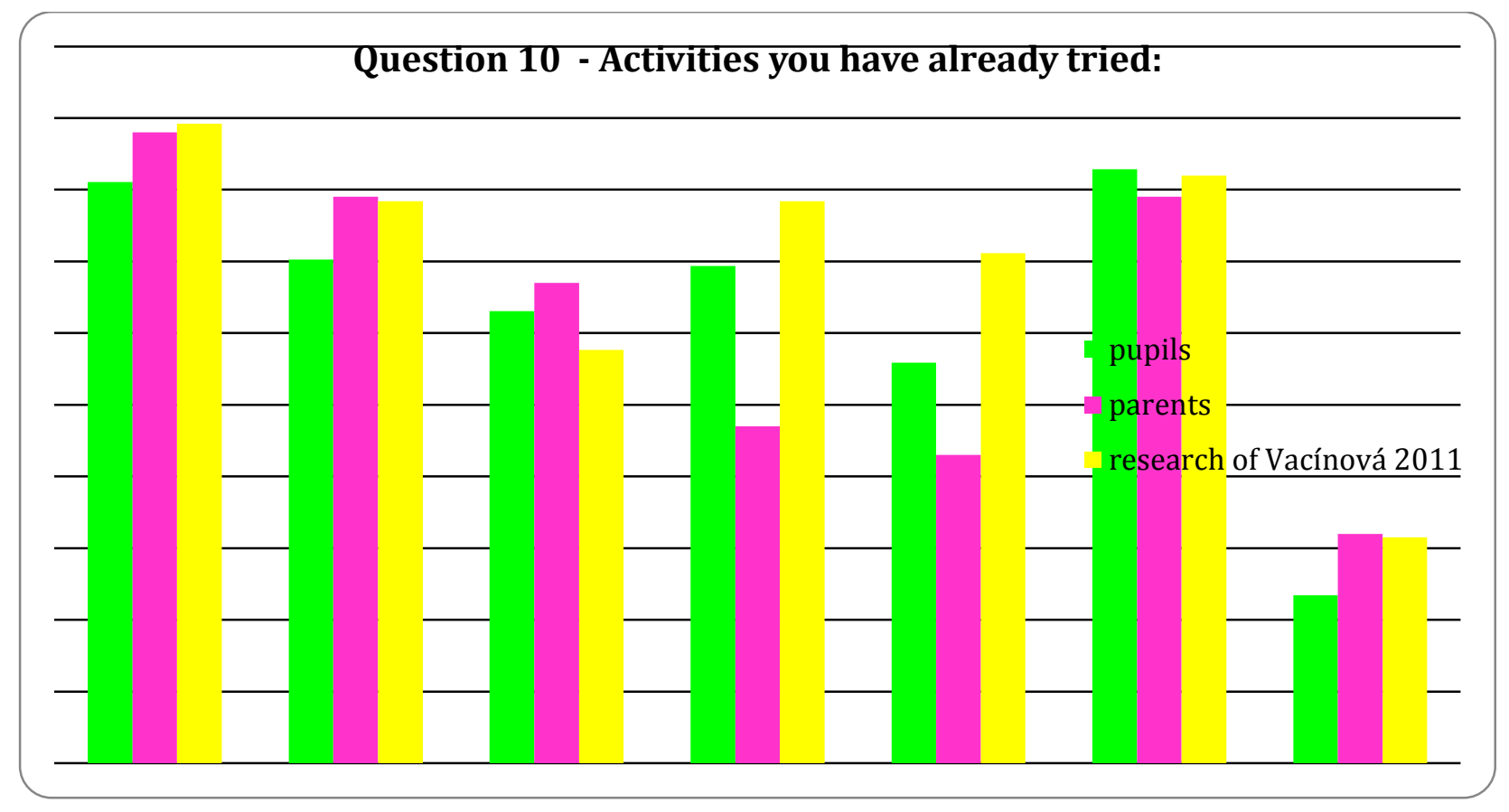

Figure 3. Evaluation of Question 10 - Activities you have already tried

$\mathrm{a}=\mathrm{I}$ have walked more than $20 \mathrm{~km}, \mathrm{~b}=\mathrm{I}$ have slept "under the stars", $\mathrm{c}=\mathrm{I}$ have spend three days "away from civilization", $d=$ I have grown vegetables, fruit and flowers from seed to mature plant, e $=\mathrm{I}$ have prepared drink or food from plants growing wild, $\mathrm{f}=\mathrm{I}$ have taken care of an animal for at least six months, $\mathrm{g}=\mathrm{I}$ have lit a fire in the rain and without the use of paper.

\section{Questions focused on environmental sensitivity}

A considerable difference between answers from the parents and the students was in claim 3/IV ("When I am in nature I feel that I hear natural sounds"). Parents agreed with this claim much more than students (Table 1 ).

In question 6, we tried to find out how much the respondents sense the actual time of sunrise and sunset. To evaluate this, 8 intervals with a range of 15 minutes were set, which expressed the amount of minutes deviating from the correct answer. The correct answer was the time between sunrise and sunset in a chosen day (day of completing the questionnaire) with a maximum deviation of 15 minutes. In the case of sunrise, the result of the pupils and the parents were comparable, the time of sunset was better answered by the parents (Figure 4). In comparison with our previous research (Vacínová 2011), where this question was also used, the students achieved better results, especially in the case of the time of sunset. 

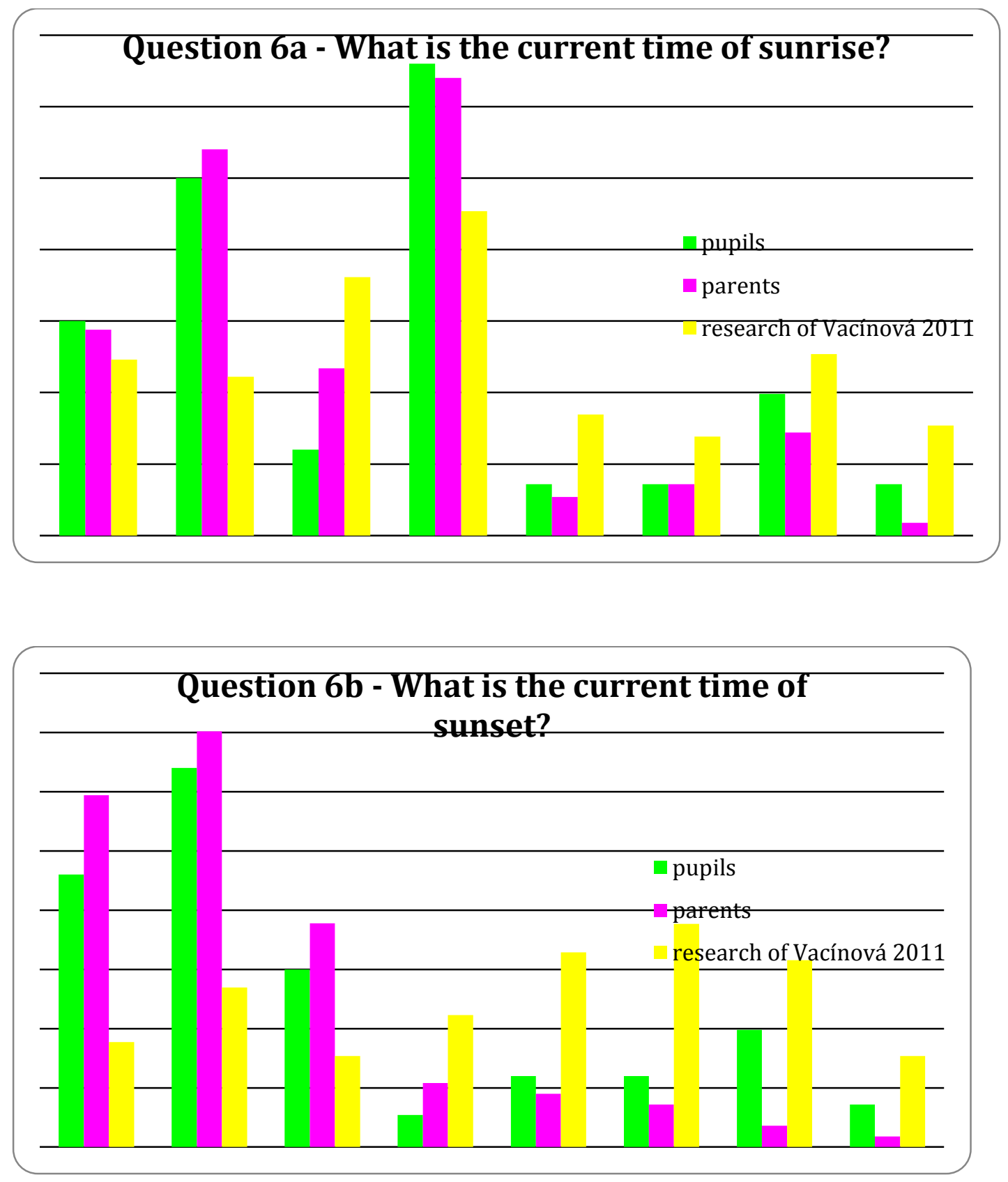

Figure 4. Evaluation of Question 6a) What is the current time of sunrise?; and 6b) What is the current time of sunset?

Question 9 also tests the environmental sensitivity of the respondent. This item in the questionnaire was taken from previous research by Kulich and Dobiášová (2003) and Vacínová (2011). It verified the ability to describe one exact place, which the respondent liked and could explain why. The gathered answers showed that almost $73 \%$ of students could describe an exact place in nature (Figure 5). That is more than $5 \%$ more than in research by Kulich and Dobiášová (2003) and more than 22\% more than in Vacínová (2011). The tested students answered this question better in line with the assignment than their parents, who rather than describing an exact favourite place stated a general description of an unspecified place (Figure 5). 


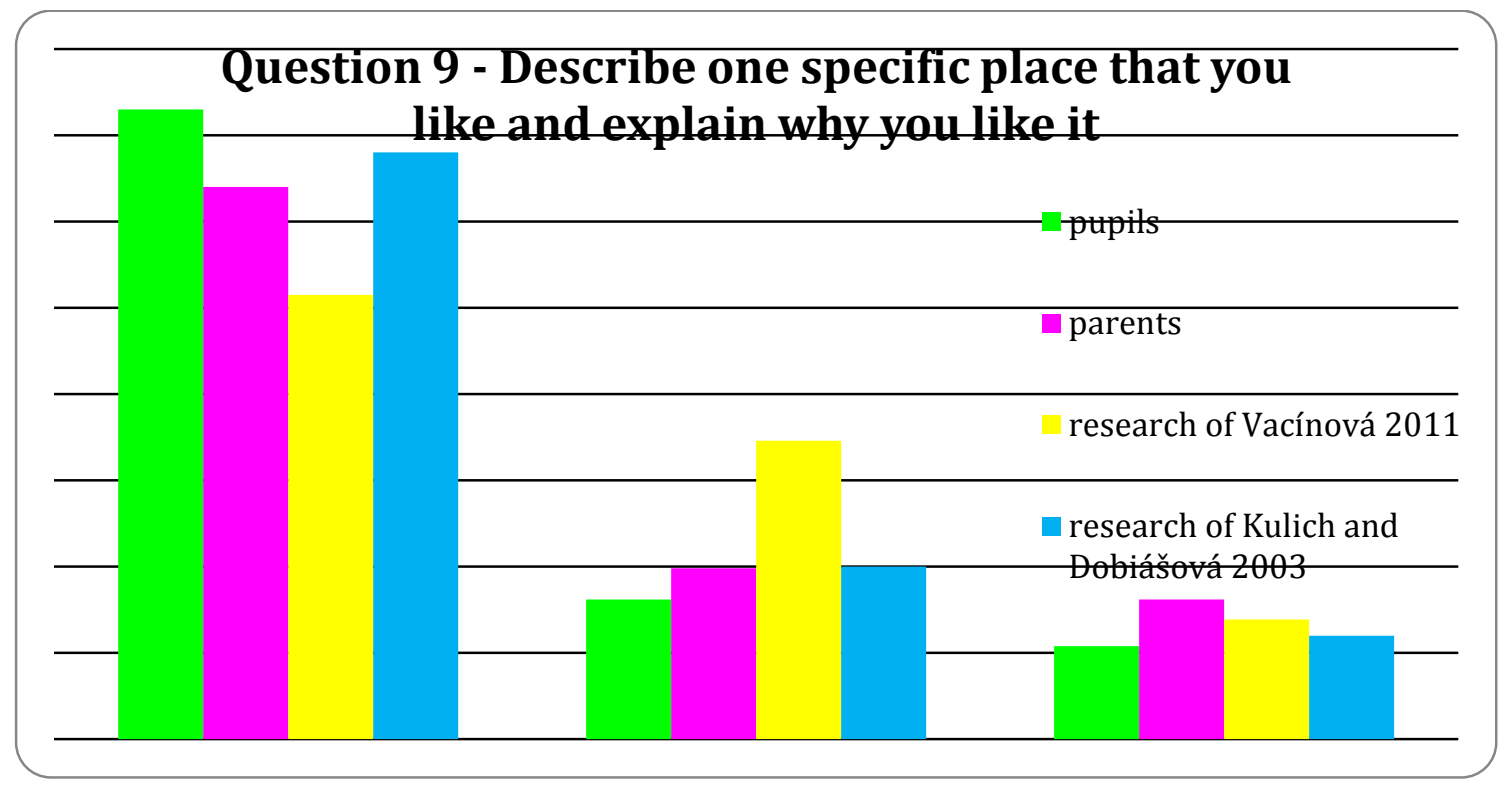

Figure 5. Evaluation of Question 9 - Describe one specific place that you like and explain why you like it.

\section{Questions focused on environmental awareness}

To identify the level of environmental awareness and environmentally friendly behaviour some parts of question 3 (claims 3/I, 3/II and 3/V - see tab. 1) and question 5 were used. The answers to claims 3/I and 3/II show a higher rate of environmentally friendly behaviour by parents. The pupil's higher level of interest in the environment (in comparison to the parents) is also evident from the answer to the claim 3/V.

Question 5 was focused on the everyday habits concerning the use of natural resources. The question provides five declarations to which the respondent expressed their opinion using the four point response scale ("always", "often", "rarely", "never").

The first declaration was meant to test whether the respondents reuse plastic bottles for drinking water, or if they always buy new plastic bottles. The answers "always" or "often" were considered as a response indicative of a higher level of environmental awareness. This answer was chosen by more than $78 \%$ of respondents, of which the pupils selected this category more often than their parents (about $12 \%$ ).

The second declaration was targeted at waste water, specifically concerning whether respondents usually leave the water running while brushing their teeth. The expected 'environmentally friendly' response in this case was the answer "rarely" or "never". These options were chosen by about $84 \%$ of all respondents, and there was no difference between the responses of the parents and the pupils.

The third declaration was aimed to discover whether the respondents completely shut down all electronic appliances from the mains when leaving home for an extended period of time. Around $45 \%$ of all respondents declared that they always or often shut down their appliances from electrical outlets. 
The aim of the fourth declaration was to determine whether the pupils and the parents usually buy a new plastic bag when going shopping. The responses received indicate that only $5 \%$ of all respondents during each purchase buy a new shopping bag.

The last declaration was aimed at the economical management of food and on wasting it. Almost $80 \%$ of all respondents said that they always or often buy only the amount of food that they really use meaning that they never throw away food. The difference between the responses of the pupils and the parents was minimal.

Overall, roughly two-thirds of all respondents to question 5 chose answers that were consistent with environmentally friendly behaviour. Responses of the pupils and the parents were significantly different only in the first declaration of question 5 (the use of a plastic bottle), in other cases they showed very similar results (Figure 6).

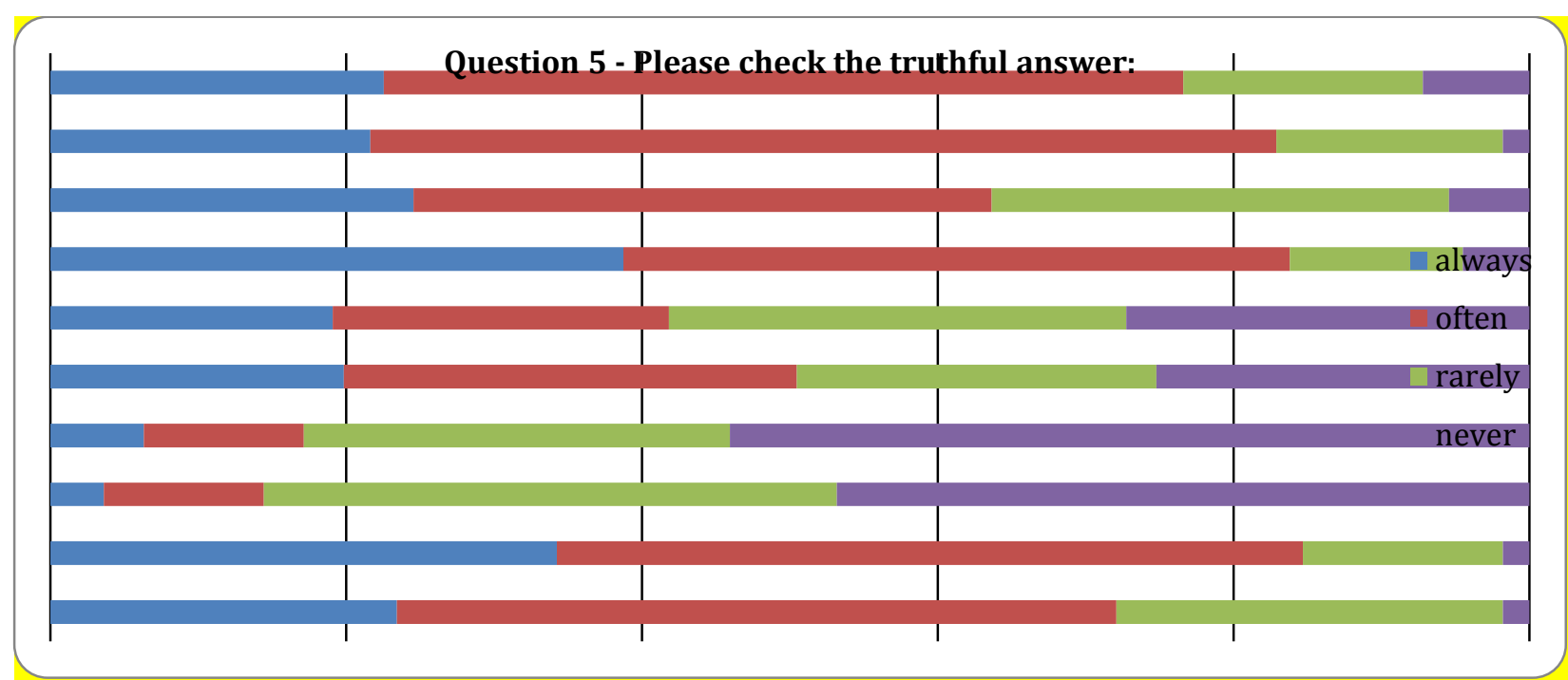

Figure 6. - Evaluation of Question 5 (for full text of claims see Appendix 1).

\section{Questions focused on attitudes towards nature}

Question 7 and partially question 11 were focused on the investigation of the overall respondents' attitude towards nature. In response to question 7, respondents had to finish the following sentence: "Nature I consider...". After reading all the questionnaires, we identified seven categories that describe the attitude of respondents to nature. $26 \%$ of all the respondents considered nature as "an important thing to be protected" (Figure 6). This answer was the most common response among the pupils (chosen by $31 \%$ of them). For $19.3 \%$ of our respondents, nature represented an "integral part of life". This answer was the most common response for parents (mentioned by $31 \%$ of the parents, on the contrary for the pupils this answer was rather unusual). $14.8 \%$ of the respondents consider nature as a "place of relaxation" (more pupils than their parents). Another $13.6 \%$ of respondents (pupils rather than parents) considered nature as "something ordinary" or "something that has always been here" or "something to be fully exploited". $8 \%$ of the respondents (pupils rather than parents) described nature as simply "wonderful" and $9 \%$ of the respondents didn't complete this question (Figure 7). 


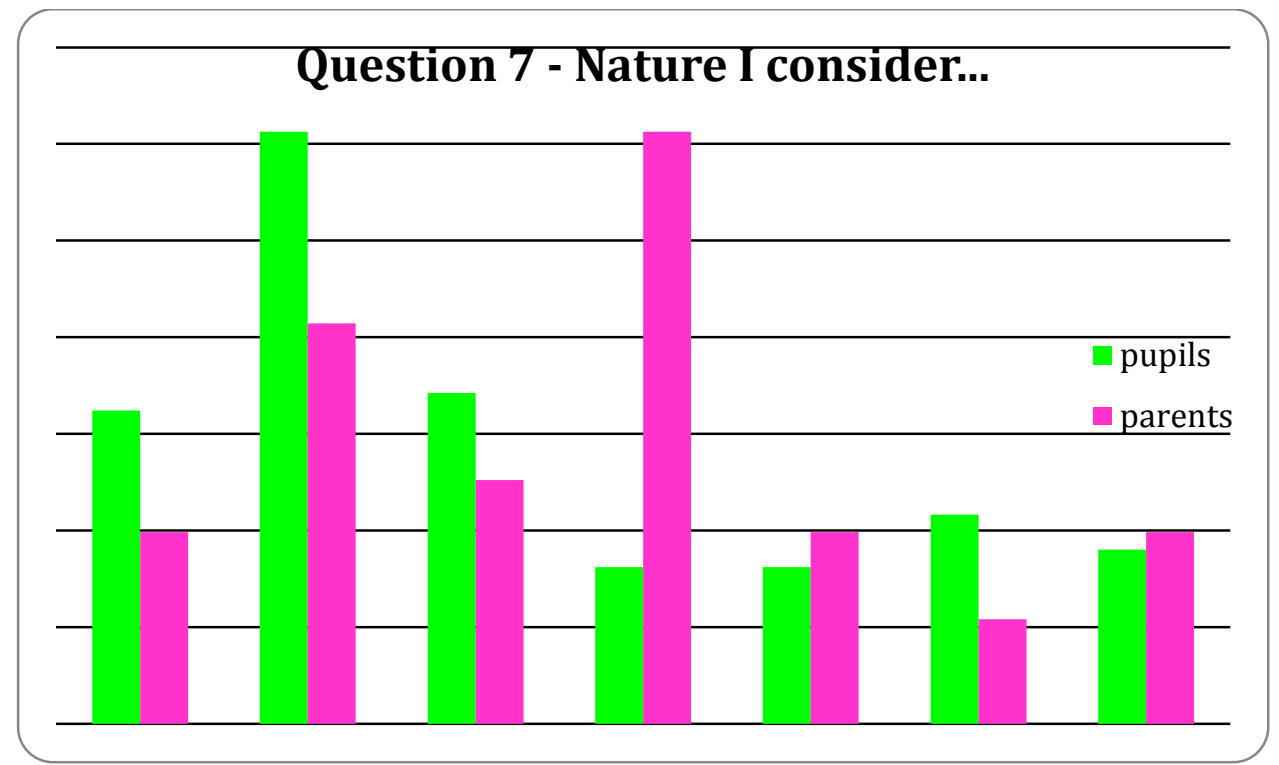

Figure 7. Evaluation of Question 7 - "Nature I consider...".

In question 11 , respondents had to write an example of a negative human-induced change in the landscape, which they consider to be the gravest. The question was designed as an open one, and since it had been used in our previous research (see Vacínová 2011), it was possible to compare the responses. To evaluate this question we used the same nine categories as in the above-mentioned research. The pupils considered as the biggest negative change caused by human activities "deforestation" - this response was named by around $36 \%$ of respondents (Figure 7). $18 \%$ of the pupils (the second most frequent response) perceive house-building the biggest change. Around $11 \%$ of pupils did not respond at all to this issue. Replies of parents were much more diverse, much of it is therefore included in the category "other" (26\%). Most of the answers in this category rather generally pointed to the presence of man on the Earth and his behaviour (such as "human behaviour as having dominion over the world", "the mere presence of man" etc. Over $14 \%$ of parents did not respond at all (Figure 7). 


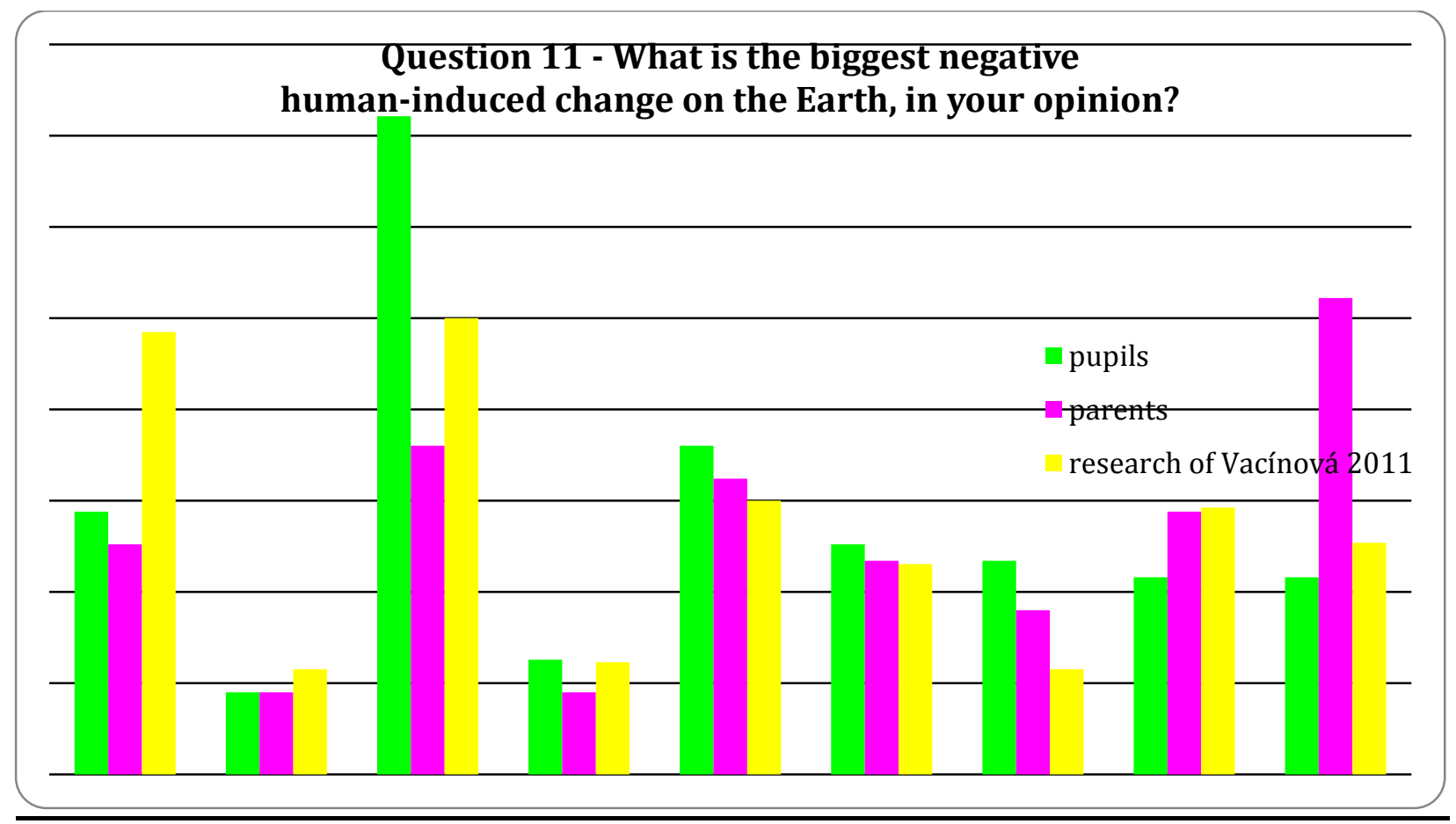

Figure 8. Evaluation of Question 11 - What is the biggest negative humaninduces change on the Earth, in your opinion?

\section{Discussion}

The aim of this paper was to summarize the results of research on intergenerational differences in personal relationships to nature. Selected characteristics were detected through a questionnaire which was completed by pupils and their parents. Answers of both groups were then compared and evaluated. The goal of this research was to find out what personal relationship adolescents (pupils of elementary school) have and how these relationships differ from their parents.

The results can be affected by many other factors. Besides the obvious factor, such as the age of the respondents, sex of the respondents could well affect the results (compare with Tuncer et al. 2005), in addition to the different conditions for completing the questionnaire (students had limited time in the lesson and they had to complete the questionnaire under the supervision of the teachers, while parents completed the questionnaire independently and the completed questionnaire was brought back within a week), the different social status of underage pupils and the adult parents, their place of birth (compare with Kasková 2008), or the individual ontogeny of psyche and other factors. Also the fact that the differences between declared attitudes and actual behaviour were detected (for further information see Činčera and Štěpánek 2007, Kasková 2008) could play an important role.

The results were also compared with the results of Vacínová (2011). Pupils of the presented research have more experience with certain activities (growing vegetables, fruit and flowers from seed to mature plant or preparing a drink or a meal from plants growing in the wild) in comparison with the respondents from the research of Vacínová (2011). Even fewer parents have experience in this respect. The time of sunrise and mainly the time of sunset were identified by pupils in this study better than by pupils in the research 
of Vacínová (2011). Our respondents were also better able to describe their favourite place.

When interpreting the results, it is also necessary to take into account that the questionnaire did not fully cover the various dimensions of personal relationships to nature, some of the dimensions are represented only by one or two questions. For example the "environmental awareness" dimension is represented only by simplest household habits, while Krajhanzl (2010) describes this dimension in a broader sense (including emotional aspects, citizenship and engagement). The obtained results can not be interpreted as general conclusions, since the research was conducted in only two schools in Prague, thus respondents therefore can not be considered as a representative sample of the whole population.

Despite these limits, the results can be inspirational for further research and also for the practical focus of environmental education. Further research could be focused mainly on the findings of the importance of various factors that affect personal relationship to nature. When studying generational differences, it would be particularly interesting to focus on the question of how strongly the educational effect of parents influenced their children in their personal relationship to nature, or whether the complex personal characteristics of an individual person play a more important role or whether other factors (school, media, friends, etc.) are dominant.

\section{Conclusions}

The research yielded some partial findings described above. We consider the following most interesting:

- About a quarter of the pupils do not seem to feel the need to go for walks in the countryside. Based on these results it might seem that students have lower need for direct contact with the natural environment in comparison with their parents.

- Domestic animals are present in two-thirds of the surveyed households. For many pupils it might represent a significant opportunity for direct contact with nature.

- Among the activities carried out in nature cycling dominates; more than half of the respondents occasionally sit by camp fires or go hiking or cycling. Some "modern activities" (especially canoeing and mountain climbing) are more often practised by the students than by their parents.

- While more pupils are identified with the skills that could be called "taking care of pets and gardening" (plant growing, taking care of animals/husbandry), their parents rather incline to the skills that could be called "hiking and camping". The parents are also more confident with their skills in orientation in nature compared to the pupils.

- While visiting the countryside, parents declare a higher degree of receptivity than pupils. However the pupils were able to specifically describe their favourite natural place better than their parents. 


\section{References}

- Činčera, J., \& Štěpánek, P. (2007). Research into environmental literacy among high school students. Envigogika, 2(1), 10-14712. Retrieved from http://www.envigogika.cuni.cz/index.php/Envigogika/article/view/12 http://dx.doi.org/10.14712/18023061.12

- Erdogan, M., \& Ok, A. (2011). An Assessment of Turkish Young Pupils' Environmental Literacy: A nationwide survey. International Journal of Science Education, 33(17), 2375-2406.

- Chráska, M. (2007). Metody pedagogického výzkumu: Základy kvantitativního výzkumu. Praha: Grada.

- Kasková, B. (2008). Testování environmentální gramotnosti u žákủ ZŠ a nižších ročníků [Diploma thesis]. Supervisor: Tomáš Matějček. Praha: Charles University in Prague.

- Krajhanzl, J. (2009). Exkurz do osobní charakteristiky vztahu k přrrodě. In: Člověk + Př́roda $=$ Udržitelnost? Texty o proměně vztahů lidí k prírodě, environmentální výchově a udržitelnosti. Praha: Zelený kruh.

- Krajhanzl, J. (2010). Charakteristika osobního vztahu člověka k prírodě. [Dissertation thesis]. Supervisor: Lenka Šulová. Praha: Charles University in Prague.

- KULICH, J., DOBIÁŠOVÁ, M., a kol., (2003). Průzkum ekogramotnosti. Bedrník, 1 (2 suplement),

- Kvasničková, D. (2007) Cíle a výsledky projektu „Ekogramotnost do pražských škol". In Švecová, M., Žáková, Z. (Ed.), Ekogramotnost: Sborník z konference s mezinárodní účastí systémového projektu JPD3 (pp. 19-42). : Charles University in Prague.

- Máchal, A. (2000). Průvodce praktickou ekologickou výchovou. Brno: Rezekvítek.

- Matějček, T., \& Bartoš, J. (2012). Environmental literacy of teachers and student of pedagogy. Envigogika, 7(2), 10-14712. Retrieved from http://www.envigogika.cuni.cz/index.php/Envigogika/article/view/75 http://dx.doi.org/10.14712/18023061.75

- Matějček, T., Vacínová, M., (2012). Environmentální gramotnost - výsledky výzkumu na pražských gymnáziích. Geografické rozhledy, 22(1), 16-17.

- McBeth, W., \& Volk, T. L. (2009). The National Environmental Literacy Project: A Baseline Study of Middle Grade Students in the United States. The Journal of Environmental Education, 41(1), 55-67. Retrieved from http://www.tandfonline.com/doi/abs/10.1080/00958960903210031 http://dx.doi.org/10.1080/00958960903210031

- Negev, M., Sagy, G., Garb, Y., Salzberg, A., \& Tal, A. (2008). Evaluating the Environmental Literacy of Israeli Elementary and High School Students. The Journal of Environmental Education, 39(2), 3-20. Retrieved from http://www.tandfonline.com/doi/abs/10.3200/JOEE.39.2.3-20 http://dx.doi.org/10.3200/JOEE.39.2.3-20 
- Schultz, W. P. (2002) Inclusion With Nature: Te Psychology of Human-Nature Relations. In. In Schuck, P., Schultz, W. K. (Ed.), Psychology of sustainable development. Boston: Kluwer Academic Publishers.

- Tuncer *, Gaye ${ }_{\prime \prime}$, Ertepinar, H., Tekkaya, C., \& Sungur, S. (2005). Environmental attitudes of young people in Turkey: effects of school type and gender.Environmental Education Research, 11(2), 215-233. Retrieved from http://www.tandfonline.com/doi/abs/10.1080/1350462042000338379 http://dx.doi.org/10.1080/1350462042000338379

- Vacínová, M. (2011). Environmentální gramotnost u studentů gymnázií. [Diploma thesis]. Supervisor: Tomáš Matějček. Praha: Charles University in Prague.

- Zecha, S. (2010). Environmental knowledge, attitudes and actions of Bavarian (southern Germany) and Asturian (northern Spain) adolescents. International Research in Geographical and Environmental Education, 19(3), 227-240. Retrieved from http://www.tandfonline.com/doi/abs/10.1080/10382046.2010.496982 http://dx.doi.org/10.1080/10382046.2010.496982 


\section{Appendix 1. Questionnaire (translation from Czech)}

Dear pupils and parents

please fill in the following questionnaire, which will serve as a basis for research on environmental topics. The questionnaire is anonymous,

and therefore we would like to ask you to give us separate responses.

School address:

Gender: Male / Female Age: Date: Symbol:

1) How often do natural motifs and plants appear in your home? Please, assign numbers according to the following characteristics $(1=$ occur disproportionately, $2=$ present in a normal way; 3 = present to a small extent, 4 = absent):

\begin{tabular}{|l|l|c|c|c|c|}
\hline a) & natural motifs & 1 & 2 & 3 & 4 \\
\hline b) & plants & 1 & 2 & 3 & 4 \\
\hline
\end{tabular}

2) Do you have pets?

a) Yes, because:

- Please specify which animal / animals it is:

b) No, because:

3) In the following statements, please choose (?)numbers 1 to 4 , depending on the extent to which you agree ( 1 = strongly agree, 2 = somewhat agree, $3=$ somewhat disagree, $4=$ strongly disagree):

\begin{tabular}{|c|l|c|c|c|c|}
\hline I. & I sort out waste regularly & 1 & 2 & 3 & 4 \\
\hline II. & I use both sides of paper (writing or printing on both sides). & 1 & 2 & 3 & 4 \\
\hline III. & Orientation in nature does not make me any problems. & 1 & 2 & 3 & 4 \\
\hline IV. & When I am in nature I feel that I hear its voices. & 1 & 2 & 3 & 4 \\
\hline V. & $\begin{array}{l}\text { I'm not interested in what is happening in my close surroundings (e.g. } \\
\text { change of use of space, transportation, construction ...) }\end{array}$ & 1 & 2 & 3 & 4 \\
\hline VI. & $\begin{array}{l}\text { If I'm in a forest during thunderstorm, I hide under a tree to protect } \\
\text { myself from rain. }\end{array}$ & 1 & 2 & 3 & 4 \\
\hline
\end{tabular}

4) I go to nature for trips:

a) never, nature doesn't attracted me

b) only when I have to (it makes my parent / partner happy) 
c) sometimes - irregularly, if I have the time and inclination

d) often

e) regularly, nature would miss me

f) other (please specify):

\section{5) Please check the true answer:}

I. I use a plastic water bottle several times.

always / often / rarely / never

II. While I brush my teeth, I leave water running.

always / often / rarely / never

III. If I leave home for a weekend, I unplug my appliances from electrical outlets.

always / often / rarely /

never

IV. I'm going to the store with my own bag, I don't buy a new bag every time.

always / often / rarely /

never

V. I buy only the amount of food that I know I will really eat (I don't throw away food).

always / often / rarely /

never

6) What is the current time of sunrise

and sunset ?

\section{7) Complete the following sentence: \\ Nature I consider...}

8) Please select the activities that you do (or you tried sometime) and indicate how often (for example, almost every day, several times a week, once a week / month / year, once every few years, etc.). Write it for the period with suitable conditions for each activity (eg. skiing in winter).
a) cross-country skiing
b) canoeing down the river
c) cycling
d) evening campfires
e) hiking
f) climbing in nature (not on artificial wall)
g) regular activity in a troop focusing on nature
h) mushroom picking
i) other (please specify):

9) Describe one specific place that you like and explain why you like it:

10) From the following activities please circle those that you have already tried: 

a) I walked more than $20 \mathrm{~km}$
b) I slept "under the stars"
c) I have spent three days "out of civilization"
d) I grew vegetables, fruit and flowers from seed to mature plant (if yes, state which one)
e) I prepared a drink or food from plants growing in the wild (if yes, specify which)
f) I've taken care of an animal for at least six months (if yes, state which)
g) I lighted fire in the rain and without the use of paper

11) What is the biggest negative human-induced change on the Earth, in your opinion? 